University of Nebraska - Lincoln

DigitalCommons@University of Nebraska - Lincoln

1978

\title{
Purification of Some Legume Carlaviruses
}

Venkateswarlu Veerisetty

University of Nebraska-Lincoln

Myron K. Brakke

University of Nebraska-Lincoln

Follow this and additional works at: https://digitalcommons.unl.edu/plantpathpapers

Part of the Plant Pathology Commons

Veerisetty, Venkateswarlu and Brakke, Myron K., "Purification of Some Legume Carlaviruses" (1978).

Papers in Plant Pathology. 176.

https://digitalcommons.unl.edu/plantpathpapers/176

This Article is brought to you for free and open access by the Plant Pathology Department at DigitalCommons@University of Nebraska - Lincoln. It has been accepted for inclusion in Papers in Plant Pathology by an authorized administrator of DigitalCommons@University of Nebraska - Lincoln. 


\title{
Purification of Some Legume Carlaviruses
}

\author{
Venkateswarlu Veerisetty and Myron K. Brakke
}

Respectively, Graduate Student, Department of Plant Pathology, University of Nebraska; and Research Chemist, Agricultural Research Service, U.S. Department of Agriculture, stationed at the Department of Plant Pathology, University of Nebraska, Lincoln, NB 68583. Present address of senior author: Department of Plant Pathology, University of Missouri, Columbia, MO 65201.

Cooperative investigations, Agricultural Research Service U.S. Department of Agriculture and Plant Pathology Department, Nebraska Agricultural Experiment Station, Lincoln, NB 68583. Published with the approval of the Director as Paper No. 5259 Journal Series, Nebraska Agricultural Experiment Station. Results are from the thesis submitted by the senior author for the Ph.D. degree.

Mention of a trademark, proprietary product, or vendor does not constitute a guarantee or warranty by the U.S. Department of Agriculture and does not imply approval of it to the exclusion of other products or vendors that also may be suitable. The name ISCO is a trademark of Instrumentation Specialties Co., Lincoln, NB 68504; Beckman instruments are made by Beckman Instruments, Inc., Palo Alto, CA 94304; Triton X-100 is a trademark for alkylphenylpolyethoxyethanol marketed by Rohm and Haas, Philadelphia, PA 19105; Cary is a trademark of Varian Inc., Palo Alto, CA 94303.

Accepted for publication 7 July 1977.

\section{ABSTRACT}

VEERISETTY, V., and M. K. BRAKKE. 1978. Purification of some legume carla viruses. Phytopathology 68:59-64.

Purification schemes were developed which yielded 0.7 to $1.0 \mathrm{mg}$ of alfalfa latent virus (ALV) and pea streak virus (PSV) and 0.1 to $0.3 \mathrm{mg}$ of red clover vein mosaic virus (RCVMV) per gram pea cullivar Lincoln ) plant tissue (excluding roots). The freezing of the tissue and the use of an appropriate extraction buffer were crucial. Virus from sap was precipitated by $6 \%(\mathrm{w} / \mathrm{v})$ polyethylene glycol(PEG, MW $6,000)$ and concentrated by two cycles of differential centrifugation. Partially purified virus preparations had a single nucleoprotein component in rate-zonal sucrose and equilibrium cesium chloride density gradient centrifugation. The virus preparations did not contain detectable impurities. The ALV, had a sedimentation coefficient of $161 \pm 1.5 \mathrm{~S}$, a value similar to other members of the carlavirus group. Both ALV and PSV multiplied and accumulated when they were inoculated to the same host plant, thus supporting the previous evidence that they are indeed different viruses.
Viruses of the carnation latent virus group (carlaviruses) (6) have been difficult to purify in sufficient quantity because of their low concentration in plant extracts and their tendency to aggregate $(5,7,10)$. Alfalfa latent virus (ALV) was isolated from alfalfa and was established as a new member of the carlavirus group (14). In repeated trials using the published purification procedures for other legume carlaviruses, we failed to obtain appreciable quantities of ALV. However, we found numerous virus particles of ALV and also pea streak virus (PSV) and red clover vein mosaic virus (RCVMV), other legume carlaviruses in leaf-dip preparations of infected Lincoln peas, which suggested that most of the virus was not extracted by the usual buffers during purification. It also indicated that virus is either adsorbed to the host components or aggregated to itself in extracts of infected plants, and requires special treatments and extraction buffers for its release. Therefore, purification procedures were investigated in an attempt to improve the yields.

Physico-chemical characterization of flexuous viruses is useful for their classification and also for determining the virus structure $(11,12,13)$. However, the viruses must be obtained in a pure state and their purity should be assessed by reliable methods before any chemical 0032-949X/78/000009\$03.00/0

Copyright ( $\odot 1978$ The American Phytopathological Society, 3340 Pilot Knob Road, St. Paul, MN 55121. All rights reserved. characterization studies are undertaken. In this report we describe purification methods that gave higher yields of virus with no detectable contamination by nonviral RNA or protein.

\section{MATERIALS AND METHODS}

Viruses and host plants. - Alfalfa latent virus (ALV) was isolated from alfalfa (Medicago sativa $\mathrm{L}$.) and later maintained in broad bean (Vicia faba L.) and pea (Pisum sativum L. 'Lincoln') (14). Initially the virus was purified from broad bean leaf tissue but later from pea cultivar Lincoln because the whole pea plant (excluding roots) could be extracted. The isolates of PSV and RCVMV (ATCC/PV110) were gifts from D. J. Hagedorn and M. A. Khan, respectively, University of Wisconsin, Madison, and also were maintained in Lincoln pea. Tobacco mosaic virus (TMV) and southern bean mosaic virus (SBMV) strains were those maintained in this laboratory.

The inoculated and systemically infected leaves of broad bean showing typical symptoms (11) were harvested 15 days after inoculation. Whole pea plants, excluding roots, were harvested 20 days after inoculation. Since ALV was symptomless in peas, usually a single plant was checked by leaf dip electron microscopy. If virus was found, it was assumed that all inoculated plants were infected. They were harvested and stored at $-20 \mathrm{C}$ before purification. 
Routine purification of alfalfa latent virus. - The tissue was homogenized in a Waring Blendor with two parts $(\mathrm{w} / \mathrm{v})$ of buffer (the buffers used are discussed in the Results section) containing $0.1 \%$ sodium diethyldithiocarbamate (DIECA) and $0.5 \%$ 2mercaptoethanol (ME). The homogenized extract was strained through cheesecloth and centrifuged at 10,000 $\mathrm{rpm}$ for $10 \mathrm{~min}$ in a Sorvall SS34 rotor. The supernatant liquid was clarified with calcium phosphate formed in situ by slow and simultaneous addition of one-twentieth volume $0.2 \mathrm{M} \mathrm{Na}_{2} \mathrm{HPO}_{4}$ and one-hundredth volume of 1.0 $\mathrm{M} \mathrm{CaCl}_{2}$ with constant stirring for 15-20 min (2), and again centrifuged at $10,000 \mathrm{rpm}$ for $10 \mathrm{~min}$. The virus was precipitated from the clarified supernatant by adding $6 \%$ (w/v) solid polyethylene glycol 6000 (PEG) followed by stirring until the PEG dissolved. The PEG-precipitated virus was collected by centrifuging at $10,000 \mathrm{rpm}$ for 10 min, and resuspended in a buffer (one-tenth the original volume of the sap) containing $1 \%$ Triton X-100. After another low-speed centrifugation, the virus suspension was layered on a pad of $10 \mathrm{ml}$ of $20 \%$ sucrose containing $1 \%$ Triton X-100 and centrifuged at 28,000 rpm for $3 \mathrm{hr}$ in a Beckman No. 30 rotor at 5 C. Pellets were resuspended in buffer containing $1 \%$ Triton X-100 and centrifuged for $10 \mathrm{~min}$ at $10,000 \mathrm{rpm}$. The virus preparations were immediately layered on pads of 5 or $10 \mathrm{ml}$ of $30 \%$ sucrose containing 1\% Triton X-100, in Beckman Ti50 or No. 30 rotor centrifuge tubes, respectively, and centrifuged at $36,000 \mathrm{rpm}$ for $90 \mathrm{~min}$ in Ti50 rotor or at $28,000 \mathrm{rpm}$ for 3 $\mathrm{hr}$ in the No. 30 rotor at $5 \mathrm{C}$. Pellets were resuspended in extraction buffer (one-tenth original molarity; without DIECA or ME) and centrifuged for $10 \mathrm{~min}$ at $10,000 \mathrm{rpm}$. The supernatant was designated "partially purified virus". All manipulations between centrifugations were at room temperature.

Electron microscopy.-The presence of virus during purification steps was monitored by electron microscopy. A drop of virus suspension was placed on carbon-backed parlodion-coated grids and the excess immediately was absorbed with blotting paper. Leaf dips were made in distilled water and the water was allowed to dry. The particles were negatively stained with a mixture of $1.5 \%$ phosphotungstate and $0.25 \%$ ammonium vanadatomolybdate, $\mathrm{pH} 6.5$.

Rate- and equilibrium-gradient centrifugation.-For rate-zonal centrifugation, sucrose density gradient columns were prepared by layering $9,9,9$, and $5 \mathrm{ml}$ of 400 , 300,200 , and $100 \mathrm{mg}$ sucrose $/ \mathrm{ml}$ in $0.0165 \mathrm{M}$ disodium phosphate, $0.0018 \mathrm{M}$ trisodium citrate, $\mathrm{pH}$ 9. After layering the partially purified virus preparation, the gradients were centrifuged for $2.5 \mathrm{hr}$ at $5 \mathrm{C}$ at $25,000 \mathrm{rpm}$ in the Spinco SW 27 rotor.

Equilibrium density gradient centrifugation utilized a cesium chloride solution with a density of about $1.3 \mathrm{~g} / \mathrm{ml}$. Virus suspension was layered on the top of the salt solution. Centrifugation was at $40,000 \mathrm{rpm}$ for $16-18 \mathrm{hr}$ in the SW 56 rotor.

Linear-log sucrose density gradient centrifugation.- Linear-log gradient columns for both nucleoprotein and nucleic acid were prepared according to the method of Brakke and Van Pelt (4). Gradients for nucleoprotein contained $0-310 \mathrm{mg}$ sucrose $/ \mathrm{ml}$ and were prepared from sucrose dissolved in $0.0165 \mathrm{M}$ disodium phosphate, $0.0018 \mathrm{M}$ trisodium citrate, $\mathrm{pH}$ 9. Gradients for RNA contained $0-325 \mathrm{mg}$ sucrose $/ \mathrm{ml}$ and were prepared in $0.5 \times \mathrm{SSC}(\mathrm{SSC}$ is $0.15 \mathrm{M} \mathrm{NaCl}, 0.015 \mathrm{M}$ sodium citrate, $\mathrm{pH} 7$ ). All gradients were allowed to stand at $4 \mathrm{C}$ at least overnight before use. The centrifuged gradient columns were monitored by an ISCO fractionator.

Criteria of purity.-The purity of the virus preparations was tested by: (i) rate and equilibrium gradient centrifugation of the virus; (ii) polyacrylamide gel electrophoresis of virus protein and nucleic acid; and (iii) sedimentation of nucleic acid on linear-log sucrose gradients.

Polyacrylamide gel electrophoresis.-RNA was analyzed on $2.5 \%$ polyacrylamide- $0.5 \%$ agarose gels. Protein was analyzed on $5 \%$ polyacrylamide cylindrical gels or $5-20 \%$ gradient slab gels. Details of the gel electrophoresis will be described elsewhere (manuscript in preparation).

Determination of virus yield.-Except for a few samples, virus concentrations were estimated from the absorbance at $260 \mathrm{~nm}$ from spectra taken with a Cary Model 14 recording spectrophotometer. Even though other workers have assumed the same extinction coefficient $\left(\mathrm{E}_{260}^{0.1 \%}=2.1\right)$ obtained for carnation latent virus (9), we assumed an arbitrary value of $E_{260}^{0.1 \%}=3.0$ not corrected for light scattering. For a more accurate estimation of the virus concentration, the virus was disrupted in SDS-phosphate disruption buffer [0.04 M $\mathrm{Na}_{2} \mathrm{HPO}_{4}, 0.01 \mathrm{M} \mathrm{NaH} \mathrm{PO}_{4}, 0.001 \mathrm{M}$ ethylenediaminetetraacetate (EDTA), 1\% SDS, 1\% 2-mercaptoethanol, $\mathrm{pH}$ 7.5] and centrifuged on linear-log gradients. The centrifuged gradient columns were scanned with an ISCO fractionator and area of the RNA zone was measured by a planimeter. The area under the RNA zone was converted into $\mathrm{A}_{260}$ units and the virus concentration was calculated from $\mathrm{A}_{260}$ units of RNA, assuming that $1 \mathrm{mg} \mathrm{RNA} / \mathrm{ml}$ has an $\mathrm{A}_{260}$ of 25 and that the virus contains about 5\% RNA, which is a typical value for filamentous viruses. Measurements of concentrations by density gradient centrifugation have a standard deviation of $\pm 2.5 \%$, but there may be a systematic error since a recovery of $90 \%$ of added $\mathrm{A}_{260}$ units was reported (3). Incomplete disruption of the virions also would give low recovery. Thus, this method gives reproducible results which are probably at least $10 \%$ lower than true values.

\section{RESULTS}

Preliminary purification of alfalfa latent virus. - Virus initially was purified from frozen, virus-infected broad bean leaf tissue. In the absence of DIECA or sodium solfite, the sap always yielded dark blue pellets after differential centrifugation. A preliminary comparison based on the $A_{260}$ of partially purified preparations from extracts made with $0.5 \mathrm{M}$ sodium orthoborate, $\mathrm{pH} 7.5$; $0.1 \mathrm{M}$ potassium phosphate, $\mathrm{pH} 7$; and $0.165 \mathrm{M}$ disodium phosphate, $0.018 \mathrm{M}$ trisodium citrate, $\mathrm{pH}$ 9, indicated that the pH 9 buffer yielded the most virus. Sap clarified with carbon tetrachloride, calcium phosphate, $1 \%$ Triton $\mathrm{X}-100$, or $0.2 \%$ Igepon $\mathrm{T}-73$ gave identical virus zones when centrifuged through linear sucrose gradients. However, $n$-butanol (8.5\%)-clarified sap yielded no virus 
zone. Unless mentioned otherwise, subsequent virus extractions were with $0.165 \mathrm{M}$ disodium phosphate, 0.018 $\mathrm{M}$ trisodium citrate buffer, $\mathrm{pH} 9$, containing $0.1 \%$ DIECA and $0.5 \%$ 2-mercaptoethanol and the extract was clarified with calcium phosphate.

Effect of freezing.-Frozen Lincoln pea tissue always yielded abundant virus, whereas fresh tissue gave lower amounts of virus and sometimes resulted in higher $\mathbf{A}_{260} / \mathbf{A}_{280}$ ratios. To investigate the effect of freezing, virus was purified from fresh and frozen pea tissue from the same source. After two cycles of differential centrifugation, absorbance curves of the virus suspensions were determined. Virus yields of about 0.1 and $0.7 \mathrm{mg} / \mathrm{g}$ tissue with $\mathrm{A}_{260} / \mathrm{A}_{280}$ ratios of 1.18:1 and 1.20:1 were obtained for fresh and frozen tissue, respectively. Freezing plant sap was not as effective as freezing plant tissue. Part of an extract from peas was frozen before low-speed centrifugation, and another part after clarification of the extract by low-speed centrifugation. After 1 day, the samples were thawed at room temperature, the virus was purified and assayed by ultraviolet (UV) absorbance. No measurable virus was obtained from the sample that was frozen after low-speed centrifugation, whereas the sample frozen without lowspeed centrifugation yielded about $80 \mu \mathrm{g}$ virus/g tissue.

Use of pH 9.0 buffers as extraction and resuspension medium.-Since our preliminary observations indicated that disodium phosphate-trisodium citrate, $\mathrm{pH} 9$, buffer extracted more virus than lower $\mathrm{pH}$ buffers, other $\mathrm{pH} 9$ buffers $(0.2 \mathrm{M}$ disodium phosphate, $\mathrm{pH} 9$, and $0.5 \mathrm{M}$ borate, $\mathrm{pH}$ 9) were investigated. Pellets collected after differential centrifugation were suspended in extraction buffer diluted 10-fold. With ALV, only the phosphatecitrate buffer gave consistent results. Disodium phosphate, pH 9, buffer sometimes yielded no virus at all, but borate buffer, $\mathrm{pH}$ 9, yielded preparations with higher $A_{260} / A_{280}$ ratios than citrate-phosphate.

Virus preparations after two differential centrifugations were layered on SW 27 linear sucrose gradient columns $(100-400 \mathrm{mg}$ sucrose $/ \mathrm{ml}$ in $0.0165 \mathrm{M}$ disodium phosphate, $0.0018 \mathrm{M}$ trisodium citrate, $\mathrm{pH}$ 9) and centrifuged at $25,000 \mathrm{rpm}$ for $2.5 \mathrm{hr}$. The borate buffer sample had a large amount of UV-absorbing material at the meniscus, but the others had only a trace. This, coupled with the high $\mathbf{A}_{260} / \mathbf{A}_{280}$ ratio, indicated the presence of nonvirion nucleic acid or nucleoprotein in the borate-extracted and resuspended sample. For an accurate comparison of virus concentration, disrupted virus was layered on linear-log gradients and the nucleic acid zone was monitored. The largest viral RNA peak was found in the virus preparation extracted in disodium phosphate-trisodium citrate, $\mathrm{pH} \mathrm{9}$, and the least in the sample extracted in borate, $\mathrm{pH} 9$. The concentrations of virus calculated from the $A_{260}$ units in the viral RNA zone in sucrose gradients was usually more than $80 \%$ of the concentration calculated from the $A_{260}$ of the preparation. This result indicated that more than $80 \%$ of the UV absorbance of the preparation was due to undegraded virions; i.e., virions with intact RNA.

Effect of age of host plant.-Lincoln pea plants 14 and 28 days old were inoculated and harvested after 20 days. After two cycles of differential centrifugation, both samples gave a $\mathrm{A}_{260} / \mathrm{A}_{280}$ ratio of 1.2:1 and yields of about

\section{$1.1 \mathrm{mg} / \mathrm{g}$ tissue.}

Effect of ethylenediaminetetraacetate. - In experiments in which $0.001 \mathrm{M}$ EDTA was added during extraction and resuspension of the PEG precipitate but was omitted during resuspension of high-speed pellets in $0.1 \times$ extraction buffer, the $A_{260} / A_{280}$ ratio of the final preparation was 1.7:1 indicating the presence of nonvirion RNA. In the absence of EDTA the ALV preparation had an $\mathrm{A}_{260} / \mathrm{A}_{280}$ ratio of 1.18:1. Similar results were also obtained for PSV, and RCVMV.

Effect of resuspension buffer.-Virus was purified as described except that after one differential centrifugation, the pellets were resuspended in $0.01 \mathrm{M}$ Tris- $\mathrm{HCl}, \mathrm{pH} 7$; $0.01 \mathrm{M}$ disodium phosphate, $\mathrm{pH} 9 ; 0.0165 \mathrm{M}$ disodium phosphate, $0.0018 \mathrm{M}$ trisodium citrate, $\mathrm{pH} 9 ; 0.01 \mathrm{M}$ sodium acetate, $\mathrm{pH} 7 ; 0.01 \mathrm{M}$ glycine, $\mathrm{pH} 7$; or $0.01 \mathrm{M}$ potassium phosphate, $\mathrm{pH}$ 7. The samples were centrifuged at low speed and then compared by UV spectrophotometry. No absorbance peak at $260 \mathrm{~nm}$ was detected in preparations in Tris- $\mathrm{HCl}$, glycine, or potassium phosphate. The samples in disodium phosphate and sodium acetate yielded 30 -fold less virus than the sample in disodium phosphate-trisodium citrate, pH 9, buffer, possibly due to greater aggregation.

Effect of 2-mercaptoethanol.-Virus precipitated by PEG and suspended in neutral potassium phosphate buffer usually was lost in the next low-speed pellet. Most of the virus from these pellets could be recovered by extraction with disodium phosphate-trisodium citrate, pH 9, buffer containing 0.5\% 2-mercaptoethanol (ME), which appeared to increase the dispersion of the virus. However, ME was not routinely used since the virus frozen in the presence of $0.5 \% \mathrm{ME}$ degraded into small particles, as observed by electron microscopy. No noticeable degradation was found in virus preparations frozen in phosphate-citrate buffer without ME. Similar results were obtained with RCVMV, and PSV. Protein and nucleic acid from the above disrupted and degraded virus preparations of ALV, PSV, and RCVMV migrated the same in gel electrophoresis as protein and nucleic acid from undegraded virus. Since the normal-sized nucleic acid was found in the ME-degraded virus preparations, the effect of ME during freezing seemed to be on the disruption of protein subunits from the virion helix, possibly resulting in the smaller "firecracker-like" particles that possess the intact nucleic acid and appear as short particles.

Challenge of pea streak virus by alfalfa latent virus. - Lincoln peas were inoculated with greatly diluted (about $10^{-3}$ ) PSV crude sap and 10 days later the same plants were inoculated with partially purified ALV (about $0.5 \mathrm{mg} / \mathrm{ml}$ ). Plants showing typical PSV symptoms were harvested, frozen, and subjected to regular purification procedure. After two cycles of differential centrifugation, about $1.3 \mathrm{mg}$ virus/g tissue was obtained. The $5-20 \%$ polyacrylamide gradient slab gel electrophoresis was conducted for the presence of and comparison of coat protein bands of ALV and PSV. Capsid protein bands of both ALV and PSV were found and stained at approximately equal density; a proof for the multiplication of both viruses in the same host.

Properties of partially purified alfalfa latent virus.-Sedimentation coefficient.-The sedimentation 
coefficient of ALV was estimated with freshly purified virus. Partially purified preparations $(0.2 \mathrm{mg} / \mathrm{ml})$ of $\mathrm{ALV}$, tobacco mosaic virus (TMV), and southern bean mosaic virus (SBMV) were layered on SW 41 linear-log gradient columns and centrifuged at $38,000 \mathrm{rpm}$ for 75 min at $6 \mathrm{C}$. The log of the migration distance was plotted against the $\log$ of the sedimentation coefficient of the internal virus standards; i.e., TMV, 190S and SBMV, $115 \mathrm{~S}$. The S-value of ALV was calculated from this straight line and was found to sediment at $161 \pm 1.5 \mathrm{~S}$ (average of four experiments).

Ultraviolet absorption.-The absorption spectrum of ALV, with maximum and minimum at $260 \mathrm{~nm}$ and 244 $\mathrm{nm}$, respectively, was typical of rod-shaped viruses (Fig. 1). The light scattering at $320 \mathrm{~nm}$ indicated partial aggregation of the virus preparations; by electron microscopy the particles appeared to aggregate side-toside. Without correction for light scattering, the $\mathrm{A}_{260} / \mathrm{A}_{280}$ absorption ratio varied from $1.15: 1$ to $1.25: 1$. That is compatible with a nucleic acid content of about $5-6 \%$, which is typical of filamentous viruses (8).

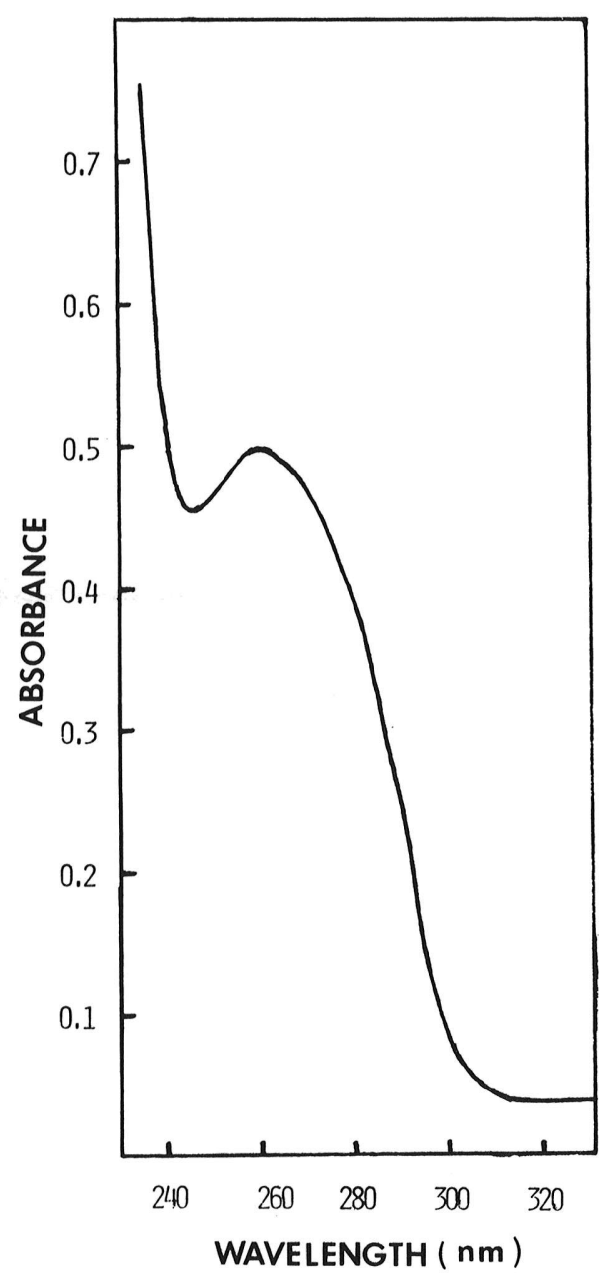

Fig. 1. Absorption spectrum of a partially purified preparation of alfalfa latent virus.
Evaluation of purity of the partially purified virus.-After two differential centrifugations, the virus samples usually were assessed for purity by gel electrophoresis of nucleic acid and protein, but occasionally by rate-zonal and equilibrium density gradient centrifugation or by electron microscopy.

Partially purified virus, after one cycle of differential centrifugation, gave a single sedimenting zone in ratezonal sucrose density gradient columns (Fig.2). The small amount of absorbance near the meniscus indicates that the partially purified virus, after passing through a $20 \%$ sucrose cushion, had some low-molecular-weight, UV-

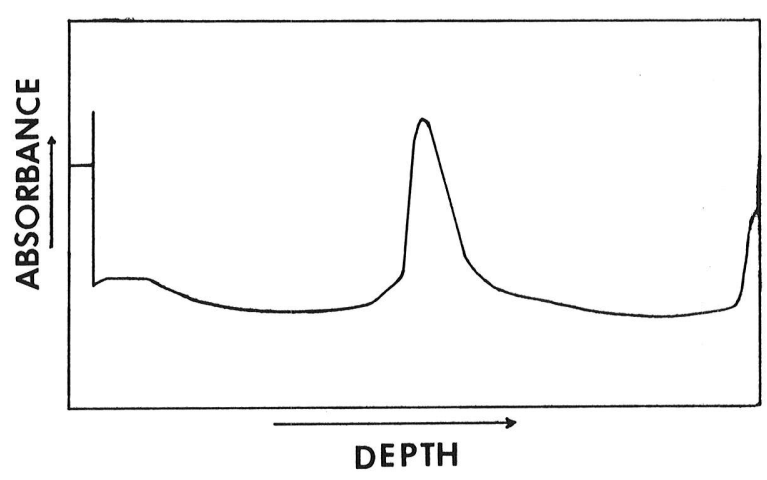

Fig.2. Scanning pattern after sucrose density gradient centrifugation of partially purified (one cycle of differential centrifugation) alfalfa latent virus. Centrifugation was at 25,000 rpm for $2.5 \mathrm{hr}$ in a Beckman SW 27 rotor at $6 \mathrm{C}$ in a linear gradient containing $100-400 \mathrm{mg}$ sucrose per $\mathrm{ml}$.

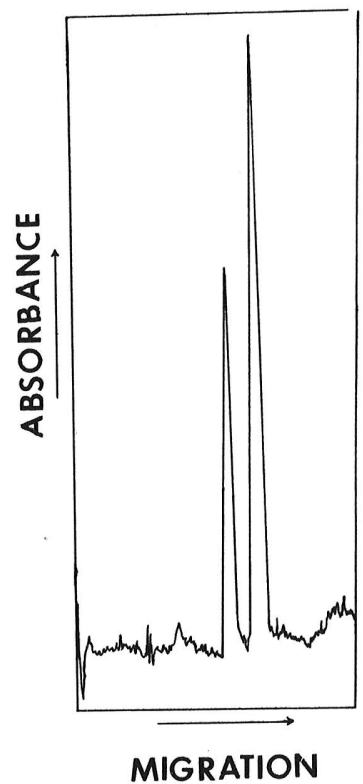

Fig. 3. Electrophoresis of proteins of alfalfa latent virus and tobacco mosaic virus (faster migrating) on 5\% SDSpolyacrylamide gels. Electrophoresis was at 8-9 mA per gel for 3$4 \mathrm{hr}$. 
absorbing impurities. However, these impurities were easily removed by a second differential centrifugation (high-speed centrifugation utilizing a $30 \%$ sucrose cushion). Virus concentrated from the gradient zone was infectious and nucleic acid prepared from partly purified virus also was infectious. Healthy pea tissue subjected to similar purification did not yield any ultraviolet absorbing peak on sucrose gradient columns. Microgram- or milligram concentrations of partially purified virus always gave a single opalescent band on cesium chloride equilibrium density gradients. The virus banded in a gelatinous mat and formed a very opalescent solution upon dilution, indicating extensive aggregation.

Only a single protein band was usually found on $5 \%$ polyacrylamide disc gels at protein concentrations of 10$75 \mu \mathrm{g} /$ gel (Fig. 3). Additional bands spaced as expected for aggregates sometimes were present. These additional bands were considered to be aggregation products because they were eliminated completely or partially when the concentration of reducing agent in the disruption buffer was increased and were also absent on gradient slab gels which utilized a different buffer system. Nucleic acid migrated as a single component on $2.5 \%$ polyacrylamide-agarose gels (Fig. 4) and on linear-log sucrose gradient columns.

Purification of pea streak virus.-Pea streak virus was purified effectively by the procedure used for ALV and in higher yield than by the method of Bos et al. (1). Usually, PSV, gave slightly higher yields (up to $1.3 \mathrm{mg}$ virus/g tissue) than ALV. Partly purified PSV had $\mathrm{A}_{260} / \mathrm{A}_{280}$ ratio about $1.15: 1$ to $1.20: 1$ and gave a single virus component in rate sucrose density gradient and cesium chloride equilibrium gradient centrifugation. A single coat protein and RNA component were found by gel

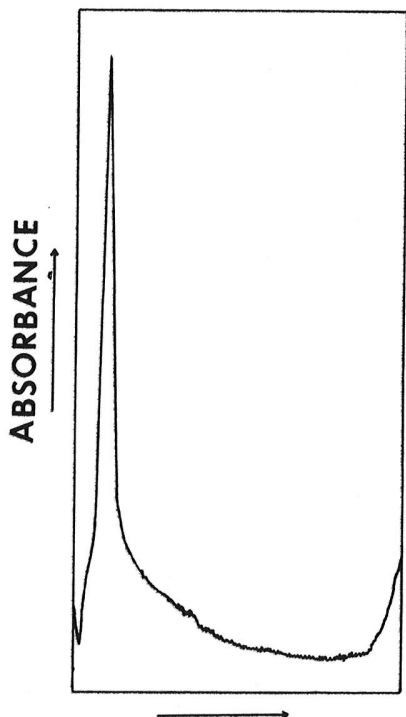

MIGRATION

Fig. 4. Electrophoresis of alfalfa latent virus RNA on $2.5 \%$ polyacrylamide $-0.5 \%$ agarose gel. Electrophoresis was at $5 \mathrm{~mA}$ per gel for 5-6 hr. electrophoresis and by linear-log gradient centrifugation, respectively.

Purification of red clover vein mosaic virus. - The purification described for ALV was slightly modified for RCVMV. Sodium sulfite $(0.1 \%)$ was substituted for DIECA and ME in extraction buffer, and the calcium phosphate clarification was omitted. The yield of RCVMV was about 0.1 to $0.3 \mathrm{mg} / \mathrm{g}$ tissue. The virus appeared to be unstable as evidenced by the presence of a 12-15S RNA in these preparations. Information on the formation and nature of the 12-15S RNA will be published elsewhere. No detectable nonvirion proteins or nucleic acids were present in the RCVMV preparations. However, $\mathrm{A}_{260} / \mathrm{A}_{280}$ ratio was usually $1.30: 1$ or more. Preliminary results suggested that the $12-15 \mathrm{~S}$ RNA is possibly a degradation product of RCVMV RNA. Further work is in progress to determine the nature of the slow-sedimenting RNA.

\section{DISCUSSION}

The presence of numerous particles of PSV, RCVMV, and ALV in leaf-dip preparations contrasts with the general belief that these viruses exist within the host in low concentrations $(1,6,10,15)$. The lower yields obtained by other workers may not have resulted solely from loss of virus by aggregation during purification, but rather from inefficient initial extraction of the infected tissue. This was clearly shown by the higher virus yields obtained from frozen tissue than from fresh tissue with our buffer system. Also, very low virus yields obtained from frozen sap (sap extracted from fresh tissue and then frozen) indicates that the critical step is the initial extraction of the virus. Freezing of tissue therefore, was an important and critical step for efficient extraction of virus. Disodium phosphate-trisodium citrate buffer, $\mathrm{pH}$ 9, was better as an extraction and resuspension medium than other buffers. Even though 2-mercaptoethanol apparently inhibited aggregation, it disrupted the particles upon freezing and was not routinely used. Age of the host plant (up to 30 days) did not have any effect on virus yields.

Partly purified ALV preparations contained a single component with a sedimentation coefficient of $161 \pm$ $1.5 \mathrm{~S}$, which is similar to the S-values of 161,160 , and 165 \pm 4 reported for the morphologically similar, naturally occurring legume carlaviruses, RCVMV, PSV, and cowpea mild mottle virus (CMMV), respectively $(1,5$, 10). Absorption spectrum and $A_{260} / A_{280}$ ratio of partially purified ALV were typical of a rod-shaped virus. Our preparations did not contain detectable impurities by sucrose or cesium chloride gradient centrifugation, by electron microscopy, or by gel electrophoresis of proteins and nucleic acids from disrupted virus. Recovery of RNA by sucrose density gradient centrifugation indicated that about $80 \%$ of the ultraviolet absorbance of the preparations was due to nondegraded virus. The yields of ALV and PSV were $0.7-1.0 \mathrm{mg}$ of virus per gram of infected plant tissue, which is higher than that previously reported for carlaviruses $(5,6,7,9,15)$. Extraction procedures and selection of buffers for resuspension of centrifuged viruses were critical factors in the yields. 
Multiplication of ALV and PSV in the same host substantiates the previous results that they are different viruses (14).

\section{LITERATURE CITED}

1. BOS, L., D. Z, MAAT, and M. MARKOV. 1972. A biologically highly deviating strain of red clover vein mosaic virus, usually latent in pea (Pisum sativum), and its differentiation from pea streak virus. Neth. J. Plant Pathol. 78:125-152.

2. BRAKKE, M. K. 1962. Stability of purified barley stripe mosaic virus. Virology 17:131-142.

3. BRAKKE, M. K. 1963. Photometric scanning of centrifuged density gradient columns. Anal. Biochem. 5:271-283.

4. BRAKKE, M. K., and N. VAN PELT. 1970. Linear-log sucrose gradients for estimating sedimentation coefficients of plant viruses and nucleic acids. Anal. Biochem. 38:56-74.

5. BRUNT, A. A., and R. H. KENTEN. 1973. Cowpea mild mottle, a newly recognized virus infecting cowpeas (Vigna unguiculata) in Ghana. Ann. Appl. Biol. 74:67-74.

6. HARRISON, B. D., J. T. FINCH, A. J. GIBBS, M. HOLLINGS, R. J. SHEPHERD, V. VALENTA, and C. WETTER. 1971. Sixteen groups of plant viruses. Virology 45:356-363.

7. LOUISONI, E., G. BOCCARDO, and R. G. MILNE. 1976.
Purification and some properties of an Italian isolate of poplar mosaic virus. Phytopathol. Z. 85:65-73.

8. PAUL, H. L. 1959. Die Bestimmung der Nucleinsäuregehaltes pflanzlicher Viren mit Hilfe einer spectrophotometrischen Methode. Z. Naturforsch., Teil C, Biochem., Biophys., Biol., Virol. 14b:427-432.

9. PAUL, H. L., and C. WETTER. 1964. Untersuchungen am carnation latent virus. 1. Preparation, physikalische und chemische Eigenschaften. Phytopathol. Z. 49:401-406.

10. VARMA, A., A. J. GIBBS, and R. D. WOODS. 1970. A comparative study of red clover vein mosaic virus and some other plant viruses. J. Gen. Virol. 8:21-32.

11. VEERISETTY, V. 1977. An observation on the number of nucleotide residues associated with a protein subunit in helical viruses. Proc. Am. Phytopathol. Soc. 4:367 (Abstr).

12. VEERISETTY, V. 1977. Nucleic acid size dependent virus structure in helical viruses. Proc. Am. Phytopathol. Soc. 4:368 (Abstr.).

13. VEERISETTY, V. 1978. Relations among structural parameters of virions of helical symmetry. Virology 52: (In press).

14. VEERISETTY, V. and M. K. BRAKKE. 1977. Alfalfa latent virus, a naturally occurring carlavirus in alfalfa (Medicago sativa L.). Phytopathology 67:1202-1206.

15. WATERWORTH, H. E. 1972. Purification, serology, and properties of a virus from lilac, Siringa oblata affinis. Plant Dis. Rep. 56:923-926. 